\title{
Polluted Waters Use in the Urban Agriculture and Its Impact on the Quality of the Grown Vegetables
}

\author{
Fabien Ilunga Mpanga and Michel Shengo Lutandula*
}

\begin{abstract}
Department of Chemistry, Inorganic Chemistry Unit, Faculty of the Sciences, University of Lubumbashi, P.O. Box 1825, Likasi Avenue, City of Lubumbashi, Haut-Katanga Province, Democratic Republic of the Congo
\end{abstract}

\begin{abstract}
Urban agriculture has become a common practice in major urban agglomerations, particularly in the mining region of Katanga, in the Democratic Republic of Congo (DRC). However, this agriculture is based on the production of vegetables grown on the soil contaminated by industrial water and domestic wastewater, wherein one finds heavy metals and pathogenic microbes capable of endangering the consumer's health. This work has been carried out in view of contributing to the consumer's health protection and endeavours at establishing, based on physicochemical and mineral analyses of water samples, the soil used in the urban agriculture and edible plants, a link between the use of contaminated waters in the urban agriculture, the build-up of heavy metals in the soil and the possible contamination by heavy metals of vegetables grown (amaranths and broccolis) in the Kasungami district and consumed by the population living in the City of Lubumbashi (DRC). The results given by the analyses of water, soils and vegetable samples revealed that, apart from cobalt, other heavy metals were present in water used in the urban agriculture to concentrations below quality standards. As for the soil, it contained heavy metals to concentration reputed phytotoxic. However, only the broccolis were contaminated with lead, contrarily to amaranths in which heavy metals were present to concentrations below quality standards. These findings enabled concluding that urban agriculture of vegetables encountered in the large agglomerations of the DRC could endanger the consumers' health and measures need to be taken in view of preventing heavy metal from entering the food chain.
\end{abstract}

Keywords: Urban agriculture, contaminated waters, soil pollution, contaminated vegetable, human health endangering.

\section{INTRODUCTION}

Urban people around the world are not only confronted with the problem of protein deficiency, which is related to the issue of hunger [1]. They are also exposed to food contamination, especially in urban centres where farming of vegetables and other fresh foods such as tomatoes, amaranth, spinach, cucumbers, broccoli, carrots, and fruits is increasingly practiced on the soils that border watercourses [2-8]. Toxic metals, brought by agricultural soils or contained in the water used at farms, accumulate in the organic tissues of various edible plants and farmed animals used as food for humans [8-10]. However, whatever the extent of the health problems, which have arisen in the industrialized and developed or developing countries up to the Second World War, none of them has been as distressing as the environment pollution associated with modern technology and the development achieved in recent decades by the mining and metals processing industry [10-12]. This increasing and worrying pollution with which both governments and the population are confronted in all developed and developing countries is

"Address correspondence to this author at the Department of Chemistry, Inorganic Chemistry Unit, Faculty of the Sciences, University of Lubumbashi, P.O. Box 1825, Likasi Avenue, City of Lubumbashi, Haut-Katanga Province, Democratic Republic of the Congo; Tel: +243842186336/ +243995084289;

E-mail: shengolutandulamichel@yahoo.fr generally the outcome of the mismanagement of mineral wastes together with wastes released by households and biomedical centres [12-14]. This increasing pollution is also the result of an accumulation of wastes in relationship with the individual consumption brought about by the population growth mainly in the developing countries and the development of industries, particularly those involved in mining and processing of raw materials [12-15]. Indeed, these industries daily release effluents that generally contain pollutants involved in the deterioration of the quality of air, water and soils resulting in increased food poisoning problems [12, 16]. In Katanga region (DRC), ancient and recent researches related to the mining industry have enabled realizing that the mismanagement of mineral wastes is responsible for the pollution of mineral origin that daily threatens the wildlife and the population's health $[11,17,18]$. Besides, previous researches on the pollution undergone by watercourses used as spillways for domestic and industrial wastewaters had succeeded establishing a close link between the contamination by heavy metals and pathogenic microorganisms of vegetables consumed in the cities of Lubumbashi and Likasi and this, provides proofs of the establishment of not friendly environmental practices in the urban agriculture mainly through the use of polluted soils and waters for growing edible plants [2, 3]. In addition, ancient researches have enabled identifying health problems associated 
with the consumption of foods affected by faecal contamination or polluted by heavy metals and especially by cadmium and lead [2, 3]. Consequently, monitoring the quality of vegetables produced around urban centres has revealed necessary in view of protecting the consumers' health threatened by the consumption of contaminated food while keeping in mind that the health of the population has no price. It is important to prevent heavy metals from entering the food chain through the watering of edible plants using contaminated waters and soils [4, 5, 19]. The present work seeks to determine whether broccolis and amaranths grown along the Kafubu River, which is located in the Kasungami district, and consumed in the City of Lubumbashi could result in food poisoning. To achieve this, samples of broccolis and amaranths and those of the soil and water used in the urban agriculture were subjected to physicochemical and mineral analyses. It is expected that the results from their characterization enable establishing a link between the pollution undergone by the water together with the build-up of heavy metals in soil used in urban agriculture as well as the contamination of broccolis and amaranths by toxic metals involved in the food poisoning $[5,7]$.

\section{MATERIALS AND METHODS}

\subsection{Research Area's Description}

This research has been carried out in the Kasungami district (Figure 1), located in the city of Lubumbashi, Katanga region (DRC). Kasungami is a peripheral area, which is not correctly urbanized. Its population is estimated at more than 800000 involved in the urban agriculture. The vegetables consumed by the population of the city of Lubumbashi are mainly grown in Kasungami. Commonly known as the "Cinq ans (in French)" district, Kasungami is separated from

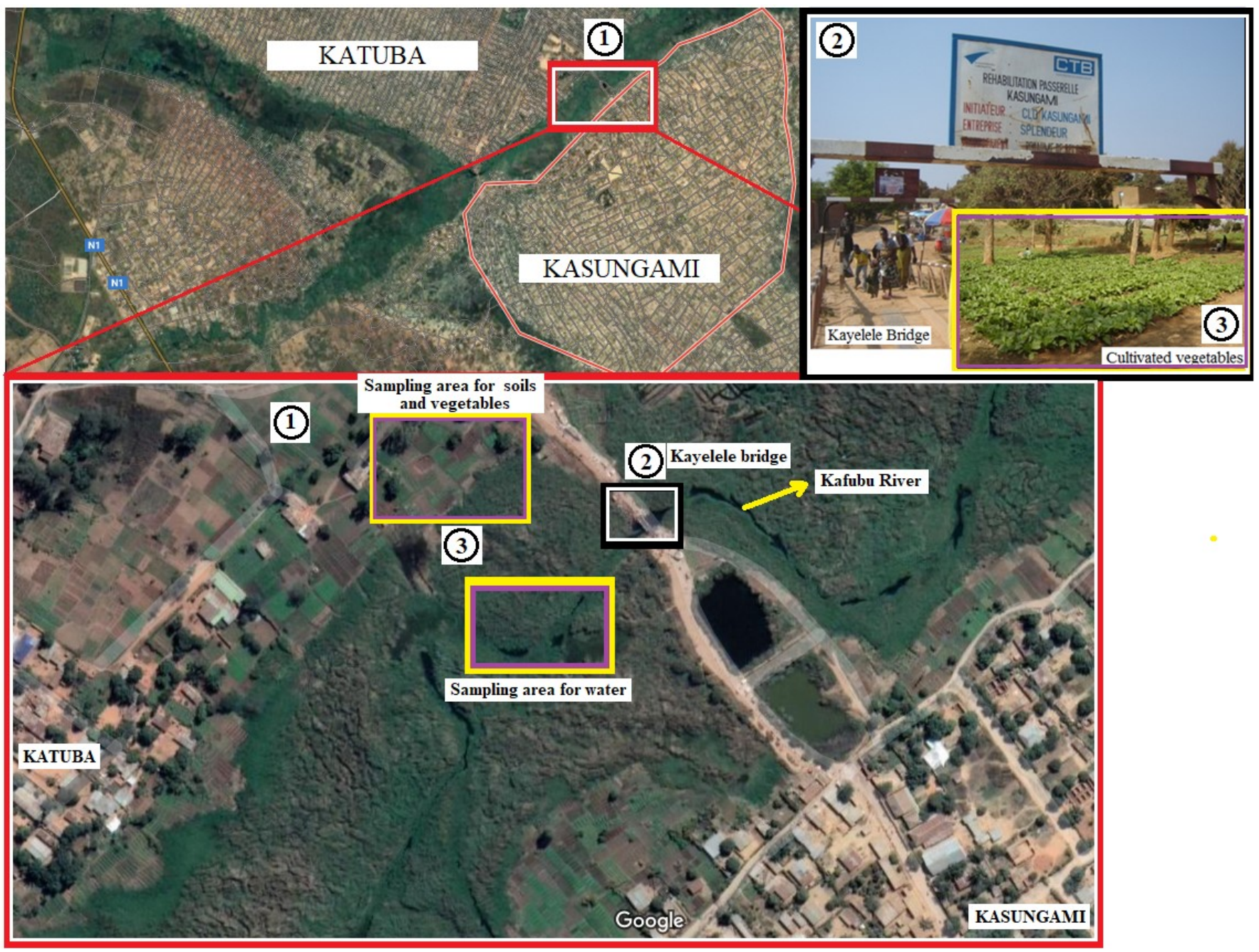

Figure 1: Vegetables grown near the Kayelele Bridge in the Kasungami District (DRC). 
the rest of the city of Lubumbashi by the Kafubu River, which constitutes the spillway for industrial and domestic wastewaters. To get in Kasungami, people have to cross the Keyelele Bridge in the vicinity of which vegetables are cultivated along the Kafubu River.

\subsection{Sampling Procedure Description}

The sampling consisted in withdrawals of representative samples of water, soils, and vegetables intended for physicochemical analyses. The sampling campaign was conducted during the period of 35 days.

\subsubsection{Water Sampling}

Ten sites were selected in the vicinity of the Kayelele Bridge in view of collecting samples of water used for watering the vegetable grown along the Kafubu River. Water samples (each of $100 \mathrm{~mL}$ ) were taken at 6:00 AM, 12 o'clock and 6:00 PM, respectively, using polyethylene made-bottles. On all of the selected 10 sites, 15 samples were collected, that is a volume of $1.5 \mathrm{~L}$ :

- 5 samples during the morning and named as $W_{1}$, $\mathrm{W}_{2}, \mathrm{~W}_{3}, \mathrm{~W}_{4}$ and $\mathrm{W}_{5}$;

- 5 samples at twelve o'clock and named as $W_{6}$, $\mathrm{W}_{7}, \mathrm{~W}_{8}, \mathrm{~W}_{9}$ and $\mathrm{W}_{10}$;

- 5 samples again during the afternoon and named $W_{11}, W_{12}, W_{13}, W_{14}$ and $W_{15}$

The sampling of water has been conducted in duplicate.

\subsubsection{Soil Sampling}

In this case, 10 sampling points were selected from vegetable gardens bordering the Kafubu River to constitute $750 \mathrm{~g}$ samples each: $\mathrm{S}_{1}, \mathrm{~S}_{2}, \mathrm{~S}_{3}, \mathrm{~S}_{4}, \mathrm{~S}_{5}, \mathrm{~S}_{6}$, $\mathrm{S}_{7}, \mathrm{~S}_{8}, \mathrm{~S}_{9}$ and $\mathrm{S}_{10}$.

\subsubsection{Sampling of Vegetables}

The vegetable gardens erected along the Kafubu River were sampled so that five samples of $100 \mathrm{~g}$ of fresh amaranth material $\left(A_{1}\right.$ to $\left.A_{5}\right)$ and $200 \mathrm{~g}$ of broccoli $\left(B_{1}\right.$ to $\left.B_{5}\right)$ were taken, respectively. These constitute the most cultivated vegetables consumed by the people from Kasungami and the City of Lubumbashi.

\subsection{Samples Preparation}

For water samples, after filtering $50 \mathrm{~mL}$, using an ashless WHATMAN - (589/2) filter paper, in view of removing suspensoids capable of clogging the sample aspiration capillary of the spectrophotometer. The aliquots $(10 \mathrm{~mL})$ of each sample were taken and poured in small plastic bottles for spectrophotometric determination of the chemical elements of interest. For the soil samples, aliquots of $2 \mathrm{~g}$ each were taken and placed in a beaker $(250 \mathrm{~mL})$ before being attacked with $20 \mathrm{~mL} \mathrm{HCl}-25 \%, 20 \mathrm{~mL} \mathrm{HNO}_{3}-65 \%$ and $8 \mathrm{~mL} \mathrm{HClO}_{4}$ - $85 \%$. After the samples attack with aqua regia, 100 $\mathrm{mL}$ of distilled water was added to each beaker before placing them on a heating plate for at least 10 minutes. The resulting solutions were allowed to cool down before transferring them to $250 \mathrm{~mL}$ graduated flasks. Subsequently, the volumes were supplemented with distilled water until the gauge mark before taking a 10 $\mathrm{mL}$ aliquot that was diluted 6250 times with distilled water in view of conducting the spectrophotometric analysis of the chemical elements of interest. For vegetables, the samples of amaranths and broccolis were placed inside a Memmert steam room $\left(105^{\circ} \mathrm{C}\right)$ for drying before being weighted using an analytic balance of the mark Mettler Toledo. Subsequently, $5 \mathrm{~g}$ of the dry plant material was collected and subjected to calcination until the obtaining of ashes. $2 \mathrm{~g}$ of the ashes given by the calcination of the samples was attacked

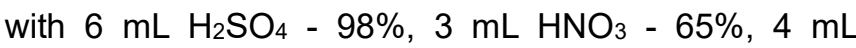
$\mathrm{HClO}_{4}-85 \%$ and $2 \mathrm{~mL} \mathrm{HCL} 25 \%$ in a $250 \mathrm{~mL}$ beaker. The acid attack was continued by placing the beaker containing the ashes on a heating plate until the obtaining of syrupy liquid, with white smoke clearing. Subsequently, the ashes' solution heating was stopped and the solution obtained cooled dow. Aliquots $(10 \mathrm{~mL})$ were collected and subjected to dilution, using the procedure implemented during the analysis of soil samples, before the spectrophotometric analysis of the chemical elements of our interest.

\subsection{Physicochemical Analyses of Samples}

Initially, these analyses consisted in the spectrophotometric measurement of the concentrations of targeted chemical elements ( $\mathrm{Cu}, \mathrm{Co}, \mathrm{Pb}, \mathrm{Mn}, \mathrm{Ni}$ and $\mathrm{Cd}$ ) in the various samples (water, soils and vegetables) using an Analytik Jena ASS 300 spectrophotometer equipped with hollow cathode lamps (multi-elements). Secondly, analyses were focused on the measurement of the water's quality parameters: $\mathrm{pH}$, contents of matters in suspension, the dissolved oxygen, total nitrogen and the determination of the electric conductivity using a Consort C933 multiparameter analyser and a $\mathrm{HACH}$ spectrophotometer for the determination of total nitrogen. 


\section{RESULTS AND DISCUSSIONS}

The results presented and discussed in this section of the paper deal with the physicochemical characterization of soil and water samples from the Kafubu River. The water abstracted from a river is used for the watering of vegetables grown in the Kasungami distric and sold to consumers living in the City of Lubumbashi. The same results are also in relationship with the mineral analysis of broccolis and amaranths samples in view of determining their respective heavy metal concentration levels.

\subsection{Determination of Physicochemical Quality of Water Samples}

Analysis of water samples collected in the vicinity of the Kayelele Bridge in the early morning hours, at noon and the last hour of the afternoon led to the results given in Table 1.

The chemical composition of the samples changes with the sampling time. These variations in the physicochemical characteristics of the water subjected to analysis can derive from changes affecting the water chemical composition given that the river daily receives different types of wastewaters coming from households as well as those released by the copper industry of which the Kafubu River constitutes the spillway. As a result, significant variations in the $\mathrm{pH}$ and the electrical conductivity of water have been observed together with changes in the content of metals namely cobalt, manganese, and copper. Discharge of domestic wastewater in the River is proven by the presence of matter in suspension and nitrogen as well as the lower dissolved oxygen content observed in samples subjected to analyses. These findings confirm the fact that the pollution undergone by the water that has become an environment more conducive to the proliferation of pathogenic microorganisms of all kinds [20] as it has been concluded based on the results from ancient researches [2, 3]. Based on the newly obtained results, it can be stated that the water from the Kafubu River knows the organic and mineral pollution and therefore, is composed of contaminated water.

As for metals of which the presence has been noticed in the water samples of our interest, their average concentrations can be classified as follows: Co $(0.097 \mathrm{mg} / \mathrm{L})>\mathrm{Mn}(0.068 \mathrm{mg} / \mathrm{L})>\mathrm{Cu}(0.029 \mathrm{mg} / \mathrm{L})>$ $\mathrm{Pb}(0.027 \mathrm{mg} / \mathrm{L})>\mathrm{Zn}(0.026 \mathrm{mg} / \mathrm{L})>\mathrm{Ni}(0.011 \mathrm{mg} / \mathrm{L})>$ Cd $(0.001 \mathrm{mg} / \mathrm{L})$. Unlike the concentrations observed for other metals in the water from the Kafubu River, it is evident that only the concentration of cobalt exceeds the limit defined by the quality standards for water intended for agricultural use [19, 21-23]. However, in spite of the fact that heavy metals are present in water under consideration, even in concentrations that are smaller than the limits set by the quality standards defined by the FAO [19, 24], the use for watering of vegetables could result in the build-up of metals in the soil and consequently, in their absorption by edible plants [10] grown (see Figure 1).

The average $\mathrm{pH}$ of the water under consideration is equal to 7.46, a value that complies with the quality standards for water intended for agricultural use. As for the dissolved oxygen and nitrogen contents, their average values are equal to $16.09 \mathrm{mg} / \mathrm{L} \mathrm{[25]} \mathrm{and} 1.97$ $\mathrm{mg} / \mathrm{L}$, respectively. As for the electrical conductivity and the amount of the matter in suspension, their average values are equal to $384.3 \mu \mathrm{S} / \mathrm{cm}$ and $246.2 \mathrm{mg} / \mathrm{L}$, respectively. These values surpass the quality standards defined for water intended for agriculture. Considering the high electrical conductivity that corresponds to the presence of chemical species in the water under study, it can be assumed that this mineral load can perturb the growth of vegetables [25]. Indeed, according to [10], the presence of heavy metals in a given plant induces oxidative stress and the displacement of essential chemical species by others and this phenomenon results in perturbation on the functioning of metabolic processes bringing about a decrease in crop yield [26]. This is the reason why Emurotu and Onianwa [27] have stated that a contaminated soil affects the rapid growth of crops and quality yield of agricultural products and thus, poses a threat to human health via the introduction of heavy metals in the food chain $[8,26]$.

\subsection{Physicochemical Quality of Soil Used for Vegetable Cultivation}

Due to the presence of metals in the water used for the watering of vegetables of our interest and considering the possibility of their build-up in the soil, samples have been collected and subjected to analyses. The results from these analyses are given in Table 2 below

The reading of the obtained results reveals that the samples are composed of soils of which the $\mathrm{pH}$ ranges between 5 and 8 . Their average $\mathrm{pH}$ is 6.6 so that all samples can be considered as composed of slightly acidic soils. It can be assumed that these soils will weakly transfer their heavy metals to the plants grown 
Table 1: Physicochemical Quality of Water from the Kafubu River

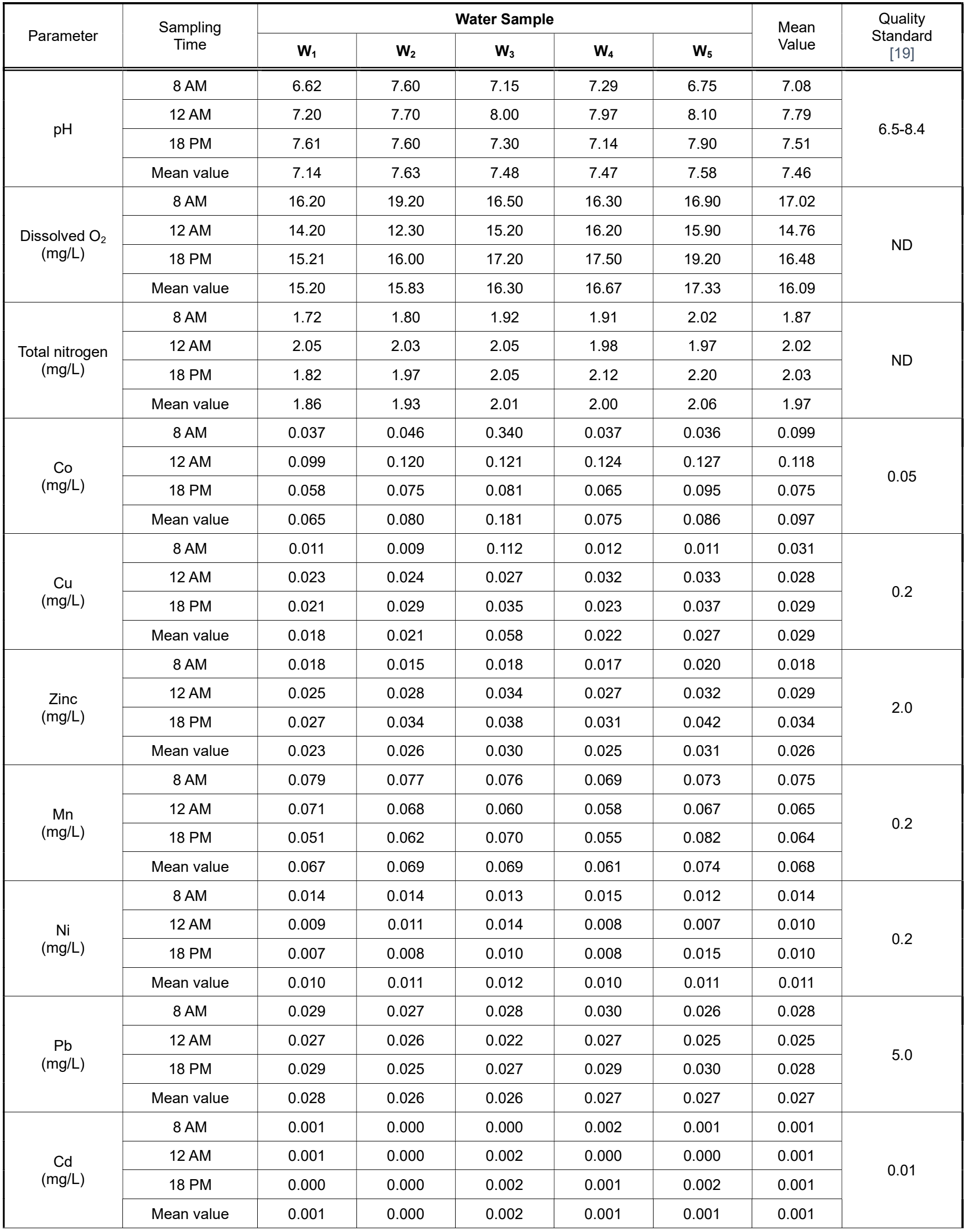


Table 1 (Contd....)

\begin{tabular}{|c|c|c|c|c|c|c|c|c|}
\hline Parameter & $\begin{array}{l}\text { Sampling } \\
\text { Time }\end{array}$ & \multicolumn{5}{|c|}{ Water Sample } & $\begin{array}{l}\text { Mean } \\
\text { Value }\end{array}$ & $\begin{array}{c}\text { Quality } \\
\text { Standarc } \\
\text { [19] }\end{array}$ \\
\hline \multirow{3}{*}{$\begin{array}{c}\text { Electric } \\
\text { conductivity } \\
(\mu \mathrm{S} / \mathrm{cm})\end{array}$} & $8 \mathrm{AM}$ & 374.0 & 374.0 & 380.0 & 385.0 & 360.0 & 374.6 & \multirow{3}{*}{$>300$} \\
\hline & $12 \mathrm{AM}$ & 378.0 & 380.0 & 374.0 & 400.0 & 420.0 & 390.4 & \\
\hline & $18 \mathrm{PM}$ & 374.0 & 382.0 & 379.0 & 400.0 & 405.0 & 388.0 & \\
\hline \multirow{3}{*}{$\begin{array}{c}\text { Suspended } \\
\text { matters (mg/L) }\end{array}$} & $12 \mathrm{AM}$ & 245.0 & 270.0 & 255.0 & 230.0 & 220.0 & 244.0 & \multirow{3}{*}{$<15$} \\
\hline & $18 \mathrm{PM}$ & 249.0 & 277.0 & 247.0 & 230.0 & 235.0 & 247.6 & \\
\hline & Mean value & 247.0 & 264.0 & 250.7 & 236.0 & 233.3 & 246.2 & \\
\hline
\end{tabular}

Table 2: Agricultural Soil Samples Physicochemical Characteristics

\begin{tabular}{|c|c|c|c|c|c|c|}
\hline Soil Sample & $\mathrm{pH}$ & $\begin{array}{c}\text { Co } \\
\text { (mg/kg) }\end{array}$ & $\begin{array}{c}\mathrm{Cu} \\
(\mathrm{mg} / \mathrm{kg})\end{array}$ & $\begin{array}{c}\mathrm{Ni} \\
(\mathrm{mg} / \mathrm{kg})\end{array}$ & $\begin{array}{c}\mathrm{Pb} \\
(\mathrm{mg} / \mathrm{kg})\end{array}$ & $\begin{array}{c}\mathrm{Cd} \\
(\mathrm{mg} / \mathrm{kg})\end{array}$ \\
\hline $\mathrm{S}_{2}$ & 5.8 & 828.1 & 188.8 & 100.0 & 628.1 & 65.0 \\
\hline $\mathrm{S}_{3}$ & 5.7 & 687.5 & 125.0 & 106.3 & 662.5 & 60.3 \\
\hline $\mathrm{S}_{4}$ & 6.8 & 656.3 & 109.4 & 81.3 & 656.3 & 62.5 \\
\hline $\mathrm{S}_{7}$ & 7.2 & 718.8 & 93.8 & 78.1 & 375.0 & 50.0 \\
\hline $\mathrm{S}_{8}$ & 6.9 & 718.8 & 140.0 & 84.4 & 437.5 & 62.5 \\
\hline $\mathrm{S}_{9}$ & 6.2 & 815.6 & 112.5 & 87.5 & 659.4 & 59.4 \\
\hline$S_{10}$ & 5.2 & 1093.8 & 131.3 & 112.5 & 781.3 & 56.3 \\
\hline $\mathrm{S}_{13}$ & 6.8 & 781.3 & 100.0 & 75.0 & 593.8 & 78.1 \\
\hline $\mathrm{S}_{14}$ & 7.7 & 531.3 & 75.0 & 62.5 & 500.0 & 46.9 \\
\hline $\mathrm{S}_{15}$ & 7.6 & 556.3 & 81.3 & 78.1 & 531.3 & 59.4 \\
\hline Mean value & 6.6 & 630.2 & 115.4 & 86.4 & 591.5 & 56.1 \\
\hline QS - European Union & ND & ND & 140 & 75 & 300 & 3.0 \\
\hline QS - Canada & ND & 40 & 150 & 150 & 375 & 3.0 \\
\hline QS - France & ND & ND & 100 & 50 & 100 & 2.0 \\
\hline QS - United Kingdom & ND & ND & 135 & 75 & 300 & 3.0 \\
\hline
\end{tabular}

QS: quality standard; ND: not defined.

on them. However, considering the individual $\mathrm{pH}$ of each sample, the soils under study can be divided in three categories composed of acidic soils $\left(S_{10}\right.$ and $\left.S_{11}\right)$, slightly acidic soils $\left(\mathrm{S}_{1}, \mathrm{~S}_{2}, \mathrm{~S}_{3}, \mathrm{~S}_{4}\right.$ and $\left.\mathrm{S}_{9}\right)$ and neutral soils $\left(\mathrm{S}_{5}\right.$, $S_{6}, S_{7}, S_{8}, S_{12}$ and $\left.S_{13}\right)$. More than half $(54 \%)$ of the samples subjected to analyses consist of neutral soils. 
Consequently, the remaining samples are composed either of the acidic or weakly acidic soils that account for only $46 \%$ of all samples. It is clear that the soils under consideration contain heavy metals of which the average concentration exceedingly surpassses the limit set by the standards in force in different countries around the world [28]. Indeed, cobalt, copper, nickel, lead and cadmium were observed in the soil samples to an average concentration that is greater than the limit set by the quality standards [28]. The content of heavy metals in soil is looked at as the main indicator of its degree of contamination [8].

Given the increased presence in the soil samples of the metals already identified in the water used for the watering of vegetables, it can be assumed that metals have accumulated in the soil and consequently, have a greater chance of ending up in the edible plants to be grown on those soil $[26,29]$. This finding supports the argument related to a possible accumulation of metals in the soils brought about by the watering of vegetables using water abstracted from the Kafubu River [4, 10, 29]. Consequently, the possibility of seeing the vegetables cultivated along the Kafubu River (broccolis and amaranths) undergoing a contamination brought about by heavy metals of which the toxicity to humans cannot be excluded $[10,29,30]$. The concerned toxic metals are present in high concentrations in soil samples taken approximately $20 \mathrm{~cm}$ from the surface.

\subsection{Chemical Composition of Vegetables Grown along the Kafubu River}

The samples of the vegetables (amaranths and broccolis) have been subjected to analyses in view of establishing a relationship between their chemical composition and the mineral pollution that they may undergo because of being grown on polluted soils. This pollution is in relationship with their watering using the water wherein heavy metals are present. The results from analyses of the vegetables are given in Tables 3 and 4.

The obtained results reveal that amaranths grown along the Kafubu River are not contaminated by toxic pollutants such as lead and cadmium considering that their average concentrations (Cd: $0.06 \mathrm{mg} / \mathrm{kg}$ and 0.04 $\mathrm{mg} / \mathrm{kg}$ ) are below the quality standards defined for

Table 3: Mineral Composition of Amaranth

\begin{tabular}{|c|c|c|c|}
\hline $\begin{array}{c}\text { Chemical } \\
\text { Element }\end{array}$ & $\begin{array}{c}\text { Average Content } \\
\text { (mg/kg) }\end{array}$ & $\begin{array}{c}\text { Phytotoxicity Range } \\
\text { (mg/kg) }\end{array}$ & $\begin{array}{c}\text { WHO Quality Standard for Edible } \\
\text { Plants (mg/kg) }\end{array}$ \\
\hline \hline $\mathrm{Co}$ & 9.37 & $15-30$ & 50 \\
\hline $\mathrm{Cu}$ & 9.0 & $30-100$ & 73.3 \\
\hline $\mathrm{Zn}$ & 23.88 & $\mathrm{ND}$ & 99.4 \\
\hline $\mathrm{Mn}$ & 15.66 & $300-500$ & 500 \\
\hline $\mathrm{Ni}$ & 0.37 & $10-100$ & 67.9 \\
\hline $\mathrm{Pb}$ & 0.04 & $30-300$ & 0.3 \\
\hline $\mathrm{Cd}$ & 0.06 & $5-30$ & 0.2 \\
\hline
\end{tabular}

Table 4: Mineral Composition of Broccoli

\begin{tabular}{|c|c|c|c|}
\hline $\begin{array}{c}\text { Chemical } \\
\text { Element }\end{array}$ & $\begin{array}{c}\text { Average Content } \\
\text { (mg/kg) }\end{array}$ & $\begin{array}{c}\text { Phytotoxicity Range } \\
\text { (mg/kg) }\end{array}$ & $\begin{array}{c}\text { Content for Edible Plants } \\
\text { (mg/kg) }\end{array}$ \\
\hline \hline $\mathrm{Co}$ & 1.50 & $15-30$ & 50 \\
\hline $\mathrm{Cu}$ & 9.09 & $30-100$ & 73.3 \\
\hline $\mathrm{Zn}$ & 21.03 & $\mathrm{ND}$ & 99.4 \\
\hline $\mathrm{Mn}$ & 3.88 & $300-500$ & 500 \\
\hline $\mathrm{Ni}$ & 0.15 & $10-100$ & 67.9 \\
\hline $\mathrm{Pb}$ & 10.72 & $30-300$ & 0.3 \\
\hline $\mathrm{Cd}$ & 0.10 & $5-30$ & 0.2 \\
\hline
\end{tabular}


edible plants $[19,28]$. The same finding applies to other metals such as copper, cobalt, manganese, nickel and zinc. In addition, the concentrations of different metals analysed are well below levels considered harzardeous to the vegetable kingdom, usually observed in tissues of plants insensitive toward heavy metals. From the above, it can be assumed that the metals observed in the soil to concentrations above quality standards are not present in the soil water in the form of bioavailable species easily absorbable by the plants via their roots. In fact, the absorption of the metals by plants from soils depends on many factors such as metal forms, plant species and parts and soil properties such as the $\mathrm{pH}$ and the redox potential [31].

As for broccoli samples (Table 4), the average concentrations of most heavy metals analyzed do not result in contamination and remain below the acceptable values for edible plants. On the contrary, broccoli is contaminated with lead observed to an average concentration of $11 \mathrm{mg} / \mathrm{kg}$, a value that is 36 times the maximum allowable level for edible plants. However, this average lead concentration is outside the range of values considered phytotoxic. It is important to recall that lead, together with arsenic and cadmium, are the metals most commonly encountered as contaminants of vegetables. These metals are involved in health problems when their concentrations become great $[8,15,26,29,31,32]$. Indeed, lead is reputed to perturb the intelligence development of children, to accumulate in the blood and is responsible for hypertension, nephropathy together with cardiovascular disease [32, 33]. Besides, it has been demonstrated that the consumption of vegetables contaminated with lead and cadmium results in a significant decrease in the human's life expectancy [15].

Overall, the obtained results reveal a link between the contamination of broccoli with lead and the mineral pollution undergone by the soil and water used in the urban agriculture practiced in Kasungami in view of producing vegetables consumed by the population living in the City of Lubumbashi. Similar researches also pointed out the contamination by cadmium of vegetables consumed in the City of Lubumbashi $[2,3]$. Based on the concentrations of the heavy metals analyzed, it can be stated that the consumption of vegetables grown in the Kasungami district can result in poising of food mainly due to the presence of lead observed in their tissues. Consequently, possible human health harms related to other heavy metals cannot be excluded or neglected in the long term, as the outcome of their bioaccumulation [26, 29, 33], although the concentrations to which they have been observed in edible plants did not exceed the toxicity limits defined by the WHO quality standards. Indeed, [4] involved in the achievement of similar researches arrived to the conclusion that long-term irrigation with wastewater can result in a build-up of heavy metals in soils owing to their strong affinity for organic matter and consequently, in foods [5, 7-9, 26, 29, 33]. Besides, the accumulation of heavy metals in edible plants has become nowadays a major international public health issue of concern [26, 33], as it has been recently acknowledged in the case of imported rice [10].

\section{CONCLUSION}

The present work, being a part of an effort to contribute to the human health protection against food poisoning that can arise due to the consumption of contaminated vegetables from the urban agriculture, what follows can be retained:

- The water from the Kafubu River that is utilized in the urban agriculture of vegetables experiences the pollution of mineral and organic origin owing to the presence of heavy metals $(\mathrm{Co}>\mathrm{Mn}>\mathrm{Cu}$ ) ordinarily encountered in wastewaters from the copper industry. The same water contains nitrogen, matters in suspension and small oxygen content so that it is likely to contribute to the contamination of the vegetables;

- The soil used to grow vegetables in Kasungami and consumed by the population living in the City of Lubumbashi has undergone the pollution of mineral origin as evidenced by the high concentrations of heavy metals $(\mathrm{Pb}$ : $375-781$ $\mathrm{mg} / \mathrm{kg}$; Cd: 47 - 78 mg/kg; Co: 531 - 1094 $\mathrm{mg} / \mathrm{kg}$; Ni: $63-113 \mathrm{mg} / \mathrm{kg}$ ). The use of this soil in urban agriculture can result in the long term in the contamination of edible plants with toxic metals;

- Mineral chemical analysis of samples of vegetables watered with water from the Kafubu River and grown on the surrounding soil showed that amaranths do not contain heavy metals to concentrations that exceed the limits set for edible plants by the WHO. The same is not true for broccoli, of which samples contain lead observed to phytotoxic levels.

Overall, the obtained results reveal a link between the contamination of vegetables grown in Kasungami and the pollution of mineral origin that has affected the 
water and soil used, exclusively in the case of broccoli. This finding justifies the banishment of unhealthy practices in urban agriculture of the vegetables consumed in the City of Lubumbashi in view of protecting the health of consumers. Further studies are therefore needed on the addressed problem in view of assessing the health risks associated with the ingestion of heavy metals through the consumption of vegetables by the population.

\section{ACKNOWLEDGEMENTS}

The authors gratefully thank the chemist Stanislas Lwangu Ngoy Piana from the laboratory in charge of the water quality of REGIDESO and the Industrial engineer and chemist André Mayombo Songo from the laboratory of the BIG HILL SMELTER IN LUBUMBASHI for their involvement in the achievement of analyses of the samples utilized in this research.

\section{REFERENCES}

[1] Sanchez, PA. Soil fertility and hunger in Africa, Science's Compass 2002; 295:2019-2020.

[2] Shengo LM, Mutiti CWN, Nonde AK, Mukadi AT. Assessment of health risks related to the intake of cabbages grown at sites contaminated by heavy metals, Journal of Chemical, Biological and Physical Sciences, Section D: Environmental Sciences 2014a; 4 (4): 3798-3808.

[3] Shengo LM, Mutiti CWN, Nonde AK, Mukadi, AT. Health issues related to the intake of cabbages grown at soils irrigated with contaminated waters, Journal of Chemical, Biological and Physical Sciences, Section B: Biological Sciences 2014b; 4 (4): 3223-3231.

[4] Deribachew B, Made M, Nigussie-Dechassa R, Taddesse AM. Selected heavy metals in some vegetables produced through wastewater irrigation and their toxicological implications in eastern Ethiopia, African Journal of Food Agriculture Nutrition and Development 2015; 15(3): 1001310032.

[5] Elbagermi MA, Edwards HGM, Alajtal Al. Monitoring of Heavy Metal Content in Fruits and Vegetables Collected from Production and Market Sites in the Misurata Area of Libya, International Scholarly Research Network, ISRN Analytical Chemistry 2012: 1-5. DOI:10.5402/2012/827645.

[6] Grubben G, Klaver W, Nono-Womdim R, Everaarts A, Fondio $\mathrm{L}$, Arie Nugteren J, Corrado M. Vegetables to Combat the Hidden Hunger in Africa, Chronica Horticulturae 2014; 54(1): 24-32.

[7] Zango MS, Anim-Gyampo M, Ampadu B. Health Risks of Heavy Metals in selected Food Crops cultivated in Smallscale Gold-mining Areas in Wassa-Amenfi-West District of Ghana, Journal of Natural Sciences Research 2013; 3 (5): 96-105.

[8] Romic M, Romic D. Heavy metals distribution in agricultural topsoils in urban area, Environmental Geology 2003; 43:795-805. DOI 10.1007/s00254-002-0694-9.

[9] Bakhshayesh BE, Delkash M, Scholz M. Response of Vegetables to Cadmium-Enriched Soil, Water 2014; 6: 12461256; doi:10.3390/w6051246.

[10] Rahimi G, Kolahchi Z, Charkhabi A. Uptake and translocation of some heavy metals by rice crop (Oryza sativa) in paddy soils. Agriculture (Pol'nohospodárstvo) 2017; 63 (4): 163-175.
Countois Y, Maurice R, Arpin M, Demers B. Étude sur la restauration des mines de cuivre et de cobalt en République Démocratique du Congo, Rapport d'étude initiale N M-6708 (603082) des recherches en République Démocratique du Congo et rédigé par SNC-Lavalin International, Division Environnement, Montréal (Canada) 2003 : pp.1-213.

[12] Briggs D. Environmental pollution and the global burden of disease, British Medical Bulletin 2003; 68: 1-24. DOI: 10.1093/bmb/ldg019.

[13] Shengo L, Mashala T, Kalenga M, Chanka L. Etude de la pollution des écosystèmes aquatiques à Lubumbashi « Cas de la rivière Lubumbashi ", Annales du CUKAM/Ext. Unilu 2007 ; 5 (1) : 76-81.

[14] Rahman MM, Howladar MF, Faruque MO Assessment of soil quality for agricultural purposes around the Barapukuria coal mining industrial area, Bangladesh: insights from chemical and multivariate statistical analysis, Environmental System research 2017; 6(24): 1-13. https://doi.org/10.1186/s40068017-0101-x.

[15] Guerra F, Ricardo Trevizam A, Muraoka T, Chaves Marcante $\mathrm{N}$, Canniatti-Brazaca SG. Heavy metals in vegetables and potential risk for human health, Scientia Agricola 2012: 69(1): 54-60.

[16] UNESCO-WWAP. L'eau pour les hommes, l'eau pour la vie, Rapport mondial sur la mise en valeur des ressources en eau, UNESCO, Dep.Eau-02, Éditions UNESCO, 7, place de Fontenoy, 75352 Paris 2003 ; p.1-31.

[17] Kaniki AT, Tumba K. Management of mineral processing tailings and metallurgical slags of the Congolese Copperbelt: Environmental stakes and perspectives, Journal of Cleaner Production 2019; 210: 1406-1413. https://doi.org/10.1016/ j.jclepro.2018.11.131.

[18] Eissa MA, Negim OE. Heavy metals uptake and translocation by lettuce and spinach grown on a metal-contaminated soil, Journal of Soil Science and Plant Nutrition 2018; 18 (4): 1097-1107.

[19] Alcalde-Sanz L, Gawlik BM. Minimum quality requirements for water reuse in agricultural irrigation and aquifer recharge Towards a water reuse regulatory instrument at EU level, EUR 28962 EN, Publications Office of the European Union, Luxembourg, 2017, ISBN 978-92-79-77176-7, DOI 10.2760/887727, PUBSY No.109291.

[20] Fipps G. Irrigation Water Quality Standards and Salinity Management Strategies, TEXAS A\&M AGRILIFE B-1667 EXTENSION 4-03, 1914.

[21] Jeong $\mathrm{H}$, Kim $\mathrm{H}$, Jang $\mathrm{T}$. Irrigation water quality standards for indirect wastewater reuse in agriculture: a contribution toward sustainable wastewater reuse in South Korea, Water 2016; 8 (169): 2-15. DOI:10.3390/w8040169.

[22] Pick T. Environment Technical Note No. MT-1 (Rev. 2), Natural Resources Conservation Service, United States Department of Agriculture, 2011; p.1-28.

[23] FAO. Water Quality for Agriculture. Paper No. 29 Rev. 1 UNESCO, Publication, Rome Anonymous, Annual Progress Report 2000-03. NATPMM Project on "Use of Urban and Industrial Effluents in Agriculture". CSSRI, Karnal-Haryana, India, 1985.

[24] George PR. Agricultural water quality criteria: irrigation aspects, Department of Agriculture and Food, Western Australia, Perth. Report 30, 1983.

[25] Di Salvatore M, Carratù G, Carafa AM. Assessment of heavy metals transfer from a moderately polluted soil into the edible parts of vegetables, Journal of Food, Agriculture and Environment 2009; 7 (2) : 683-688.

[26] Emurotu JE, Onianwa PC. Bioaccumulation of heavy metals in soil and selected food crops cultivated in Kogi State, north central Nigeria, Environmental System research 2017; 6(21): 1-9. DOI 10.1186/s40068-017-0098-1. 
[27] WHO. Directives OMS Pour l'utilisation sans risque des eaux usées, des excréta et des eaux ménagères, Utilisation des eaux usées en agriculture, Volume III, Geneva 2012 :p.1219.

[28] Behbahaninia A, Mirbagheri SA. Investigation of Heavy Metals Uptake by Vegetable Crops from Metal-Contaminated Soil, World Academy of Science, Engineering and Technology 2008; 43: 56-58.

[29] Sahu RK, Katiyar S, Tiwari, Kisku GC. Assessment of drain water receiving effluent from tanneries and its impacts on soil and plants with partuclar emphisize on bioaccumulation of heavy metals, Journal of Environmental Biology 2007; 28(3): 685-690.

[30] Tasrina RC, Rowshon A, Mustafizur AMR, Rafiqul I, Ali MP. Heavy Metals Contamination in Vegetables and its Growing Soil, Journal of Environmental Analytical Chemistry 2015; 2(3): 1-6. DOI:10.4172/2380-2391.1000142.
[31] Hang Zhou, Wen-Tao Yang, Xin Zhou, Li Liu, Jiao-Feng Gu, Wen-Lei Wang, Jia-Ling Zou, Tao Tian, Pei-Qin Peng, BoHan Liao. International Journal of Environmental Research and Public Health 2015; 13 (289): 1-12. DOI: 10.3390/ijerph13030289.

[32] Sepehri M, Zokaei M, Rezvani M, Zarei A. Comparison of the concentration of heavy metals in some vegetables (celery, broccoli and lettuce), Amazonia Investiga 2018; 7 (16): 324334.

[33] Sardar K, Ali S, Hameed S, Afzal S, Fatima S, Shakoor MB, Bharwana SA, Tauqeer HM. Heavy Metals Contamination and what are the Impacts on Living Organisms, Greener Journal of Environmental Management and Public Safety 2013; 2 (4): 172-179.

DOI: https://doi.org/10.15377/2410-3624.2020.07.5

(C) 2020 Mpanga and Lutandula. Published by Avanti Publishers.

This is an open access article licensed under the terms of the Creative Commons Attribution Non-Commercial License (http://creativecommons.org/licenses/by-nc/3.0/) which permits unrestricted, non-commercial use, distribution and reproduction in any medium, provided the work is properly cited. 